\title{
Growth inhibition of Enterococcus mundtii in Kefir by in situ production of bacteriocin ST8KF
}

\author{
Jillian E. POWELL ${ }^{\mathrm{a}}$, Svetoslav D. TODOROV ${ }^{\mathrm{b}}$, Carol A. VAN REENEN ${ }^{\mathrm{b}}$, \\ Leon M.T. DICKS ${ }^{b}$, R. Corli WITTHUHN ${ }^{a *}$ \\ a Department of Food Science, Stellenbosch University, Private Bag X1, 7602 Matieland, \\ South Africa \\ b Department of Microbiology, Stellenbosch University, Private Bag X1, 7602 Matieland, \\ South Africa
}

Received 14 June 2006 - Accepted 16 August 2006

\begin{abstract}
Lactobacillus plantarum ST8KF, isolated from Kefir grains, produces a $3.5 \mathrm{kDa}$ bacteriocin (bacST8KF) active against Enterococcus mundtii ST. Kefir produced with grains containing $L$. plantarum ST8KF prevented the growth of E. mundtii ST in situ. No inhibition of E. mundtii ST was recorded when Kefir was produced from grains containing a plasmid-free and bacteriocin-negative variant (ST8KF-). Cells of E. mundtii ST were detected by fluorescent in situ hybridization (FISH). This is the first report on the incorporation of a bacteriocin-producing starter culture in Kefir grains and in situ control of microbial growth.
\end{abstract}

Kefir / mass-cultured grains / bacteriocin ST8KF / Lactobacillus plantarum

摘要 - 开菲尔原位产生的细菌素 ST8KF 对蒙特肠球菌的生长抑制作用。从开菲尔粒中分离 出来的植物乳杆菌 (Lactobacillus plantarum) ST8KF 可以产生 $3.5 \mathrm{kDa}$ 的细菌素 ST8KF, 该 细菌素对 Enterococcus mundtii ST (蒙特肠球菌) 具有生长抑制作用。由含有植物乳杆菌 ST8KF (L. plantarum ST8KF) 的开菲尔粒发酵产生的开菲尔对 E. mundtii ST 的生长有抑制作 用, 而无质粒和细菌素阴性变异体的开菲尔粒发酵产生的开菲尔对 E. mundtii ST 的生长没 有抑制作用。采用荧光素原位杂交法 (FISH) 对 Enterococcus mundtii ST 细胞进行了原位观 察。本文首次报道了通过原位控制微生物的生长, 高密度培养富含植物乳杆菌 ST8KF 高产 细菌素 ST8KF 的开菲尔粒。

关键词 开菲尔 / 开菲尔粒的高密度培养 / 细菌素 ST8KF / 植物乳杆菌

Résumé - Inhibition de la croissance d'Enterococcus mundtii dans le kéfir par la production in situ de la bactériocine ST8KF. Lactobacillus plantarum ST8KF, isolée de grains de kéfir, produit une bactériocine (bacST8KF) de 3,5 kDa. Dans cette étude, du kéfir a été produit avec L. plantarum ST8KF dans le but de suivre la production de la bactériocine in situ. La croissance de E. mundtii ST était inhibée dans le kéfir ainsi obtenu. Aucune inhibition n'a été observée dans les kéfirs obtenus à partir de grains contenant le variant sans plasmide et le variant bactériocine-négative $\left(\mathrm{ST} 8 \mathrm{KF}^{-}\right)$. Les cellules de E. mundtii ST ont été détectées par hybridation de fluorescence in situ (FISH).

kéfir / grain cultivé en masse / bactériocine ST8KF / Lactobacillus plantarum

* Corresponding author (通讯作者): rcwit@sun.ac.za 


\section{INTRODUCTION}

Kefir is a fermented milk product with a slightly acidic taste, yeasty flavor and creamy consistency [12]. The starter cultures, which consist mainly of lactic acid bacteria, propionibacteria and yeasts, are entrapped in Kefir grains held together by polysaccharides $[6,12]$. The antimicrobial activity of Kefir has been well documented and the beverage is known to inhibit a number of spoilage microorganisms and foodborne pathogens, including Bacillus cereus, Clostridium tyrobutyricum, Escherichia coli, Listeria monocytogenes and Staphylococcus aureus [12, 18]. The reason for growth inhibition is not known, but may be due to the presence of lactic acid, volatile acids, hydrogen peroxide [4, 13], carbon dioxide, diacetaldehyde, acetaldehyde and bacteriocins [3]. The possibility of organic acids being responsible for antimicrobial activity was ruled out by growth inhibition obtained with $\mathrm{pH}$-neutralized Kefir [7]. In at least one paper [1], antimicrobial activity was associated with antimicrobial peptides. Filter-sterilized Kefir treated with trypsin lost all activity [1], suggesting that growth inhibition could be caused by bacteriocins.

Bacteriocins are ribosomal synthesized proteins or peptides with activity against genetically closely related species [5, 14]. They are grouped into four classes, based on structure, mode of action, genetic origin, biochemical properties and spectrum of antimicrobial activity. The genetic determinants of most bacteriocins are located on plasmids, with only a few exceptions being chromosomally encoded. Little is known about the regulation of these peptides and in situ production [8].

The aim of this study was to incorporate Kefir grains with a bacteriocin-producing strain of Lactobacillus plantarum (ST8KF) and study the production of the bacteriocin (bacST8KF) in situ. Enterococcus mundtii ST served as a target organism. The results were compared with Kefir produced with a plasmid-free and bacteriocin-negative strain $\left(\mathrm{ST} \mathrm{KF}^{-}\right)$.

\section{MATERIALS AND METHODS}

\subsection{Growth conditions}

Lactobacillus plantarum ST8KF [10] isolated from Kefir grains, and E. mundtii ST from the culture collection of the Department of Microbiology, University of Stellenbosch, were cultured in MRS broth (Biolab, Biolab Diagnostics, Midrand, South Africa). The strains were stored at $-80{ }^{\circ} \mathrm{C}$ in MRS broth (Biolab), supplemented with $15 \%$ (v/v) glycerol.

\subsection{Isolation of plasmid DNA from L. plantarum ST8KF}

Plasmid DNA was isolated from $24 \mathrm{~h}$ old cells using the Qiagen Plasmid Midi Kit (Southern Cross Biotechnology, Cape Town, South Africa). Excess proteins were removed by an additional phenol treatment. Plasmid DNA was visualized by separation on $1 \%(\mathrm{~m} / \mathrm{v})$ agarose [17].

\subsection{Plasmid curing}

Plasmid curing was performed as described by Ruiz-Barba et al. [11]. Strain ST8KF was grown in MRS broth (Biolab), supplemented with $5 \mu \mathrm{L} \cdot \mathrm{mL}^{-1}$ to $320 \mu \mathrm{L} \cdot \mathrm{mL}^{-1}$ Novobiocin (Sigma, St Louis, USA) and $0.1 \mathrm{mg} \cdot \mathrm{mL}^{-1}$ to $1.0 \mathrm{mg} \cdot \mathrm{mL}^{-1}$ SDS, respectively, and inoculated with $0.3 \%$ (v/v) L. plantarum ST8KF. After $48 \mathrm{~h}$ at $30{ }^{\circ} \mathrm{C}$, cultures resistant to the highest concentration of Novobiocin and SDS were selected, streaked onto MRS agar (Biolab) and incubated at $30^{\circ} \mathrm{C}$ for $48 \mathrm{~h}$. Colonies were randomly selected and tested for bacteriocin activity according to the tripleagar-layer method [15]. Isolates without zones of growth inhibition were selected and plasmid DNA isolated as described before.

\subsection{Carbohydrate fermentation reactions}

Carbohydrate fermentation reactions of L. plantarum ST8KF and ST8KF- were determined using the API 50 CHL test kit according to the instructions of the 
manufacturer (bioMérieux ${ }^{\circledR}$ S.A., Marcy L'Étoile, France).

\subsection{Mass cultivation and enrichment of Kefir grains}

For the mass cultivation of Kefir grains full cream milk (400 mL), supplemented with $20 \mathrm{~g} \cdot \mathrm{L}^{-1}$ yeast extract (Biolab) and $5.0 \mathrm{~g} \cdot \mathrm{L}^{-1}$ urea (Biolab), was pasteurized $\left(90 \mathrm{~min}\right.$ at $\left.80^{\circ} \mathrm{C}\right)$ and inoculated with Kefir grains $(40 \mathrm{~g})$ from a stock culture. Fermentation was at $25^{\circ} \mathrm{C}$ in a shaking water bath $(120 \mathrm{rpm})$. Every $24 \mathrm{~h}$ the grains were sieved and replenished with pasteurized milk of the same composition.

Lactobacillus plantarum ST8KF and ST8KF- $^{-}$were cultured, separately, in $50 \mathrm{~mL}$ MRS broth (Biolab) to $1 \times 10^{8} \mathrm{cfu} \cdot \mathrm{mL}^{-1}$, and the cells were harvested $(6000 \times g$, $10 \mathrm{~min}, 4^{\circ} \mathrm{C}$ ) and re-suspended in $1 \mathrm{~mL}$ sterile physiological salt. This was used to inoculate $20 \mathrm{~g}$ mass-cultured grains suspended in $200 \mathrm{~mL}$ pasteurized milk, supplemented with yeast extract and urea. Fermentation was at $25{ }^{\circ} \mathrm{C}$ at $120 \mathrm{rpm}$. Grains were sieved every $24 \mathrm{~h}$ and replenished with pasteurized milk of the same composition. Inoculation with L. plantarum ST8KF and ST8KF- was every $48 \mathrm{~h}$. Enrichment was for 40 days at $25^{\circ} \mathrm{C}$ at $120 \mathrm{rpm}$.

In a separate experiment, $5 \mathrm{~g}$ mass-cultured grains, and $5 \mathrm{~g}$ grains enriched with L. plantarum ST8KF and ST8KF-', respectively, were added to $50 \mathrm{~mL}$ pasteurized full cream milk inoculated with $0.2 \%(\mathrm{v} / \mathrm{v})$ of an 18 h-old culture of $E$. mundtii ST. Fermentation was for $24 \mathrm{~h}$ at $22^{\circ} \mathrm{C}$.

\subsection{Fluorescent in situ hybridization (FISH)}

Grains were sieved from Kefir containing E. mundtii $\mathrm{ST}$ and the cells hybridized in situ (FISH) with a DNA probe obtained from amplification with primers STF (TGAGAGAAGGT) and STR (TCCACTGAAAT). PCR was performed according to the method described by [19]. The probe was 5'-labeled with fluorescein isothiocyanate (Invitrogen, Karlsruhe, Germany). One $\mu \mathrm{L}\left(250 \mathrm{ng} \cdot \mathrm{mL}^{-1}\right)$ of the probe was added to a Kefir sample. Optimal stringency required the addition of $35 \%(\mathrm{v} / \mathrm{v})$ hybridization buffer $\left(180 \mu \mathrm{L} 5 \mathrm{~mol} \cdot \mathrm{L}^{-1}\right.$ $\mathrm{NaCl}, 20 \mu \mathrm{L} 1 \mathrm{~mol} \cdot \mathrm{L}^{-1}$ Tris, $450 \mu \mathrm{L}$ MilliQ water, $350 \mu \mathrm{L}$ formamide and $1 \mu \mathrm{L} 10 \%, \mathrm{~m} /$ $\mathrm{v}$, SDS). Hybridizations were performed at $46{ }^{\circ} \mathrm{C}$ for 90 to $150 \mathrm{~min}$. Fluorescence was detected with a Nikon eclipse E400 microscope (Innovative Met Products (IMP), Somerset-West, South Africa) equipped with a Nikon super high-pressure mercury lamp. Ten optical fields were counted for each sample, in triplicate.

\section{RESULTS AND DISCUSSION}

\subsection{Plasmid isolation and curing}

Lactobacillus plantarum ST8KF harbors at least 6 plasmids (Fig. 1). Growth in the presence of $80 \mu \mathrm{L} \cdot \mathrm{mL}^{-1}$ Novobiocin resulted in the loss of a $3.9 \mathrm{~kb}$ plasmid and the ability to produce bacST8KF (Fig. 1). Growth in the presence of SDS did not result in plasmid loss or changes in bacST8KF activity. Based on these results, the genes encoding bacST8KF production are located on the plasmid. This is in agreement with most other reports for bacteriocins of $L$. plantarum. The genes coding for plantaricin 423 and plantaricin $\mathrm{C} 11$ are located on bigger plasmids of approximately $9 \mathrm{~kb}[9,17]$. Only a limited number of plantaricins are encoded by genes located on the genome, e.g. plantaricin UG1 [2] and plantaricin ST31 [16].

\subsection{Carbohydrate fermentation reactions}

Different fermentation reactions were recorded for $L$. plantarum ST8KF and $\mathrm{ST} \mathrm{KF}^{-}$. Strain ST8KF- lost the ability to metabolize D-mannose, D-mannitol, D-sorbitol, methyl- $\alpha$-D-mannopyranoside, amygdalin, arbutin, salicin, D-cellobiose, D-lactose, D-saccharose, D-trehalose, D-melezitose and gentiobiose. The genes encoding the metabolism of these sugars may be located on plasmid pST8KF. 


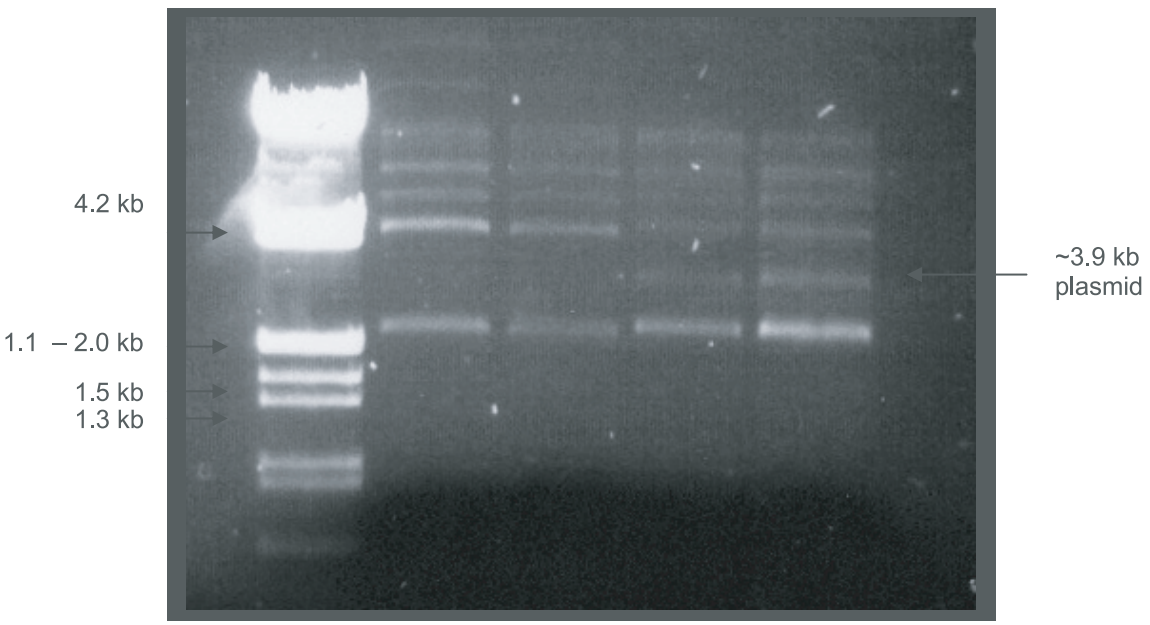

Figure 1. Agarose gel electrophoresis showing no plasmid DNA present in the cured strain, $L$ plantarum ST8KF- (lanes 2 and 3 ) and the presence of a $3.9 \mathrm{~kb}$ plasmid in the wild-type strain, $L$. plantarum ST8KF (lanes 4 and 5). Lane 1: Lambda marker, digested with EcoRI and HindIII (Roche, Indianopolis, IN, USA).

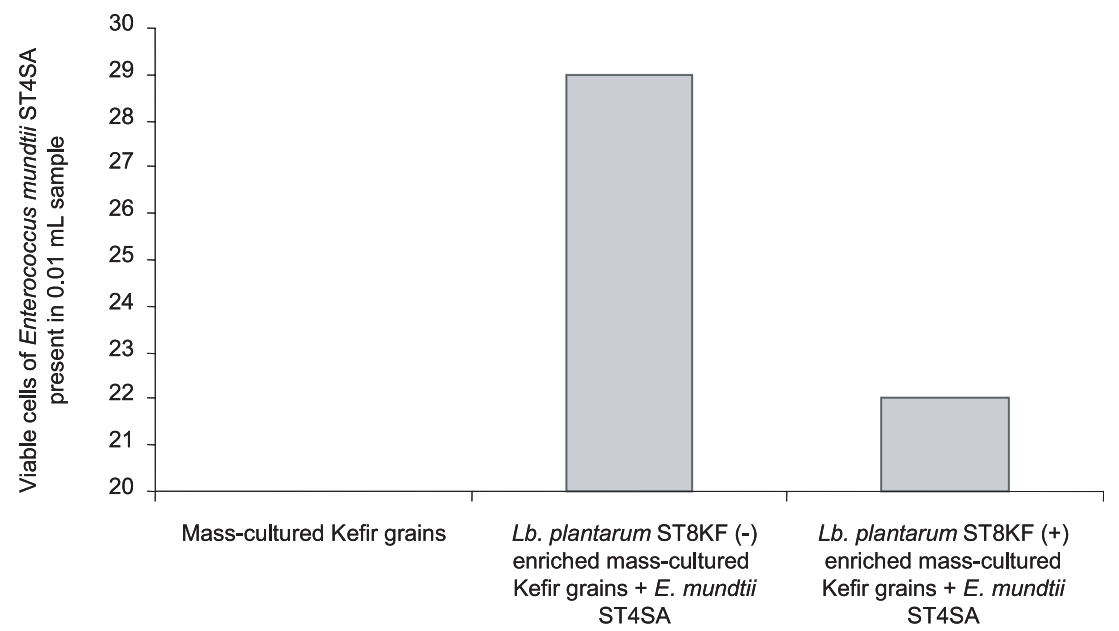

Figure 2. Survival of $E$. mundtii ST in Kefir produced from grains enriched with L. plantarum strains ST8KF and ST8KF-, respectively. Enterococcus mundtii ST were recorded by FISH.

\subsection{Survival of $E$. mundtii ST in Kefir}

Low cell numbers of $E$. mundtii were recorded in Kefir produced with $L$. plantarum ST8KF (Fig. 2). However, high cell numbers of $E$. mundtii (28 cells per
$10 \mu \mathrm{L}$ sample) were recorded in Kefir produced with L. plantarum ST8KF- (Fig. 2). Concluding from these results, the Kefir grains were successfully enriched with $L$. plantarum ST8KF, with the level of bacST8KF production high enough to inhibit the growth of E. mundtii ST. Lactobacillus 
plantarum ST8KF could be used as a starter culture in Kefir production.

Acknowledgements: The National Foundation for Research (NRF), South Africa is thanked for their financial support.

\section{REFERENCES}

[1] Balasubramanyam B.V., Varadaraj M.C., Dahi as a potential source of lactic acid bacteria active against foodborne pathogenic and spoilage bacteria, J. Food Sci. Technol. 31 (1994) 241-243.

[2] Enan G., El-Essawy A.A., Uyttendaele M., Debevere J., Antibacterial activity of Lactobacillus plantarum UG1 isolated from dry sausage: characterization, production and bactericidal action of plantaricin UG1, Int. J. Food Microbiol. 30 (1996) 189-215.

[3] Helander I.M., von Wright A., MattilaSandholm T.M., Potential of lactic acid bacteria and novel antimicrobials against Gramnegative bacteria, Trends Food Sci. Technol. 8 (1997) 146-150.

[4] Juven B.J., Schved F., Linder P., Antagonistic compounds produced by a chicken intestinal strain of Lactobacillus acidophilus, J. Food Prot. 55 (1992) 157-161.

[5] Klaenhammer T.R., Bacteriocins of lactic acid bacteria, Biochimie 70 (1988) 337-349.

[6] Kwak H.S., Park S.K., Kim D.S., Biostabilization of kefir with a non-lactose-fermenting yeast, J. Dairy Sci. 79 (1996) 937-942.

[7] Morgan S.M., Hickey R., Ross R.P., Hill C., Efficient method for the detection of microbiologically-produced antibacterial substances from food systems, J. Appl. Microbiol. 89 (2000) 56-62.

[8] Naidu A.S., Bidlack W.R., Clemens R.A., Probiotic spectra of lactic acid bacteria (LAB), Critical Rev. Food Sci. Nutr. 38 (1999) 13-126.

[9] Olasupo N.A., Bacteriocins of Lactobacillus plantarum strains from fermented foods, Food Microbiol. 41 (1996) 130-136.
[10] Powell J.E., Witthuhn R.C., Todorov S.D., Dicks L.M.T., Characterization of bacteriocin ST8KF produced by a Kefir isolate $L a c$ tobacillus plantarum ST8KF, Int. Dairy J. (2006) doi: 10.1016/j.dairyj.2006.02.012.

[11] Ruiz-Barba J.L., Piard J.C., Jiménez-Diaz R., Plasmid profiles and curing plasmids of $\mathrm{Lac}$ tobacillus plantarum strains isolated from green olive fermentations, J. Appl. Bacteriol. 71 (1991) 417-421.

[12] Saloff-Coste C.J., Kefir. Nutritional and Health Benefits of yoghurt and fermented milks, Danone World Newsletter 11 (1996) 1-7.

[13] Shahani K.M., Chandan R.C., Nutritional and healthful aspects of cultured and culturecontaining dairy foods, J. Dairy Sci. 62 (1979) 1685-1694.

[14] Tagg J.R., Dajani A.S., Wannamaker L.W., Bacteriocins of Gram-positive bacteria, Bacteriol. Rev. 40 (1976) 722-756.

[15] Todorov S.D., Dicks L.M.T., Lactobacillus plantarum isolated from molasses produces bacteriocins active against Gram-negative bacteria, Enzyme Microbiol. Technol. 36 (2005) 318-326.

[16] Todorov S., Onno B., Sorokine O., Chobert J.M., Ivanova I., Dousset X., Detection and characterization of a novel antibacterial substance produced by Lactobacillus plantarum ST 31 isolated from sourdough, Int. J. Food Microbiol. 48 (1999) 167-177.

[17] Van Reenen C.A., Chikindas M.L., van Zyl W.H., Dicks L.M.T., Characterisation and heterologous expression of a class IIa bacteriocin, plantaricin 423 from Lactobacillus plantarum 423, in Saccharomyces cerevisiae, Int. J. Food Microbiol. 81 (2003) 29-40.

[18] Van Wyk J., Britz T.J., Myburgh A.S., Arguments supporting Kefir marketing to the low-income urban African population in South Africa, Agrekon 41 (2002) 43-62.

[19] Zendo T., Eungruttanagorn N., Fujioka S., Tashiro Y., Nomura K., Sera Y., Kobayashi G., Nakayama J., Ishizaki A., Sonomoto K., Identification and production of a bacteriocin from Enterococcus mundtii QU2 isolated from soya, J. Appl. Microbiol. 99 (2005) 1181-1190. 